\title{
PKM PELWAP Desa Sea Mitra Untuk Pemanfaatan Tumbuhan Obat Dan Tanaman Hias
}

\author{
Dingse Pandiangan*1, Nelson Nainggolan² \\ ${ }^{1}$ Jurusan Biologi FMIPA Universitas Sam Ratulangi Manado Indonesia \\ ${ }^{2}$ Jurusan Matematika FMIPA Universitas Sam Ratulangi Manado Indonesia \\ *Penulis Korespondensi. Email: dingsepan@unsrat.ac.id
}

\begin{abstract}
ABSTRAK
Para Perempuan dan Ibu rumah tangga yang tergabung dalam suatu organisasi PELWAP GPdI Sea Mitra perlu penerapan Program Kemitraan bagi Masyarakat untuk mengatasi masalah kehidupan rumah tangga dan kesehatan serta kebugaran secara fisik. Melalui penerapan sosialisasi pemanfaatan tumbuahn obat dan tanaman hias serta diberikan minuman teh herbal minuman fungsional tentu menambah kebugaran fisik dan mental secara berkesinambungan. Metoda penerapan PKM dilakukan secara bertahap mulai dari pemberian panduan secara digital tentang pemanfaatan tumbuhan obat dan hias disekitar rumah dipadukan dengan gerakan senam jantung serta dilakukan pelatihan bagi UKM Biovina dan dibuatkan model taman percontohan tumbuhan obat sekaligus tanaman hias yang bermanfaat sebagai pangan juga meningkatkan pendapatan keluarga dimasa pandemik covid 19 ini. Target dan luaran kegiatan PKM ini adalah memberikan motivasi dan inovasi yang baru kepada masyarakat terutama kepada Ibu-Ibu rumah tangga yang tergabung dalam Pelayanan Wanita (PELWAP) GPdI Sea Mitra untuk mampu mengelola waktu dan kebugaran fisiknya di rumah saja (WFH) yang dapat mendukung kesejahteraan bekerja dan rumah tangga serta sekaligus kesejahtraan dan keamanan lingkungan. Hasil sosialisasi dimasa Pandemi Covid 19 ini dilakukan melalui kegiatan Vidio Conference dengan Google Meet seperti yang ditayangkan pada youtube https://youtu.be/o6Sq_sex9z0, diperoleh melalui kegiatan PKM ini dapat meningkatkan semangat ibu-ibu rumah tangga untuk memiliki pola hidup sehat dengan menggunakan tumbuhan sekitar sebagai tumbuhan obat sekaligus tanaman hias dan suka bersenam kebugaran yang menjadi gaya hidup sehingga rumah tangganya bahagia yang diawali dengan ibu rumah tangga yang bijaksana dan sehat. Hasil lainnya menciptakan tradisi baru di Desa Sea Mitra untuk menggunakan tumbuhan obat dan hias disekitar rumah serta berolah raga senam 1 kali setiap minggunya (minimal) dirumah masing-masing dengan memberikan rekaman senam jantung sehat bagi ibu-ibu di rumah saja.
\end{abstract}

Kata Kunci: Tumbuhan Obat, Hias, Jantung Sehat, PKM, PELWAP Sea Mitra

\begin{abstract}
Women and housewives who are members of the PELWAP GPdI Sea Mitra organization need to implement the Partnership Program for the Community to overcome problems in household life and physical health and fitness. Through the application of socialization on the use of medicinal and ornamental plants and being given herbal tea drinks, functional drinks certainly increase physical and mental fitness on an ongoing basis. The method of implementing PKM is carried out in stages starting from providing digital guidance on the use of medicinal and ornamental plants around the house combined with heart exercise movements as well as training for UKM Biovina and creating a model garden for medicinal plants as well as ornamental plants that are useful as food as well as increasing family income in the future. this covid 19 pandemic. The target and output of this PKM activity is to provide new motivation and innovation to the community, especially for housewives who are members of the GPdI Sea Mitra Women's Service (PELWAP) to be able to manage their time and physical fitness at home (WFH) which can support welfare. work and household as well as welfare and environmental safety. The results of the socialization during the Covid 19 Pandemic were carried out through the Vidio Conference activity with Google Meet as shown on youtube https://youtu.belo6Sq_sex9z0, obtained through this PKM activity can increase the enthusiasm of housewives to have a healthy lifestyle by using the surrounding plants are medicinal plants as well as ornamental plants and like to exercise fitness which is a lifestyle so that the household is happy starting with a wise and healthy housewife. Another result created a new tradition in the Village of Sea Mitra to use medicinal and ornamental plants around the house and to do gymnastics once a week (at least) at each home by providing recordings of heart healthy exercises for mothers at home only.
\end{abstract}




\section{PENDAHULUAN}

Pandemi Covid 19 (Corona Virus Desease 2019) merupakan masalah global yang bukan saja menyebabkan penyakit yang menyebabkan kegalalan pernapasan (pneumonia), juga menyebabkan kematian yang cepat. Covid 19 dapat menyebar melalui kehidupan manusia dan sangat mudah bermutasi, cepat menyebar serta dapat hidup di udara dan permukaan alat-lat disekitar beberapa (sekitar 3-8) jam. Sifat Covid-19 tersebut menunjukkan bahwa penggunaan vaksin menjadi tidak dapat diharapkan dan obat belum ditemukan. Akibatnya menimbulkan perubahan dan berdampak pada segala aspek kehidupan (mental, sosial, ekonomi dan budaya) yang menyebabkan terjadi perubahan peradapan manusia (new normal). Menurut kami tim pengusul bahwa solusinya adalah memanfaatkan Sumber Daya Alam Indonesia terutama tumbuhan obat dan hias disekitar kita agar bisa hidup berdampingan dengan Covid 19. Dengan memanfaatkan tumbuhan obat sebagai suplemen yang bisa dibawa kemana saja yang praktis yang dapat meningkatkan kekebalan tubuh (immunomodulator) yang juga dapat menekan penyakit degenerative (kanker, jantung, hipertensi, diabetes, kolesterol, Alzheimers, asam urat, ginjal, lever, asma, alergi dan lainnya). Orang yang memiliki penyakit degeneratif tersebut sangat rentan infeksi Covid 19. Data WHO menunjukkan bahwa pasien Covid 19 yang meninggal hampir semuanya memiliki komplikasi dengan penyakit degeneratif tersebut.

Olahraga pada Ibu-Ibu dapat menjaga stamina dan mengurangi stress, membangun kekuatan tubuh dan mempertahankan keseimbangan dalam aktivitas sehari-hari serta memperbaiki postur tubuh, membantu menurunkan berat badan yang berlebihan, menjaga Kebugaran kardiovaskular, Kebugaran kulit dan mengurangi resiko osteoporosis pada masa menopause nanti (Giriwijoyo, 2003).

Survei Departemen Kebugaran (Anonim, 2001) menyebutkan bahwa seiring berjalannya waktu penyakit degeneratif terus meningkat. Misalnya penyakit kardiovaskular sebagai penyebab kematian telah meningkat dari urutan ke 11 pada tahun 1972, menjadi urutan ke 3 pada tahun 1986, dan menjadi urutan pertama pada tahun 1992, 1995, dan 2001. Hasil survey tahun 2001 juga menyatakan bahwa 56\% penduduk (27\% pria dan $29 \%$ Ibu-Ibu) berusia 25 tahun ke atas menderita hipertensi, 3\% penduduk mengalami penyakit jantung, 1,2\% penduduk mengalami diabetes, dan 5,9\% (1,3\% pria dan 4,6\% Ibu-Ibu) mengalami kelebihan berat badan (Anonim, 2002). Berdasarkan analisis data kebugaran yang dikumpulkan pada kegiatan SDI (Sport Development Index) 2006 menunjukkan perempuan $37,40 \%$ masuk dalam kategori kurang sekali, 43,90\% kurang, 13,55\% sedang, dan hanya $5,15 \%$ yang masuk kategori baik dan baik sekali (Anonim, 2007). Hasil penelitian atau pemetaan Departemen Kebugaran tahun 2002 menyebutkan bahwa lebih dari $63 \%$ memiliki tingkat kebugaran fisik yang sangat kurang. Selain itu pada tahun 2005 dilakukan survei tingkat kebugaran pada pelajar dan hasilnya $10,71 \%$ masuk kategori kurang sekali, 44,97\% masuk kategori kurang, 37,66\% masuk kategori sedang dan 5,66\% masuk kategori baik, sementara itu yang masuk kategori baik sekali 0\% (Mutohir dan Maksum, 2007).

PELWAP GPdI Sea Mitra berada di Perumahan Sea Mitra memiliki keanggotaan terdiri dari seluruh kaum ibu dan perempuan yang berjemaat di GPdI Sea Mitra. Keanggotaannya berada pada usia yang bervariasi mulai usia 17- sampai 80 tahunan. Jemaat yang ada sekitar 25-35 kepala keluarga, tidak menetap sebab masyarakat Sea Mitra ini kebanyakan masih berpindah-pindah dan banyak yang kost atau kontrak rumah. Jadi Pelayanan Wanita di PELWAP tersebut sekitar 
50 orang jika semuanya hadir. Kebanyakan IbuIbu PELWAP di GPdI Sea Mitra ini tidak ada perkerjaan menetap atau hanya ibu rumah tangga. Sehingga perilaku hidup mereka gampang tersinggung atau negative thinking setiap ada pengarahan, hal itu juga karena pengaruh tekanan darah tinggi dan sakit degeneratif lainnya. Hal tersebut menjadi pemicu pertengkaran di sekitar dan jemaat, halhal sepele bisa menjadi perkara yang besar istilah Minahasa "tasontong sadiki tapela besar". Keadaan ini mendorong perlu diberikan kegiatan tambahan dan berbagi pengalaman untuk memanfaatkan tumbuhan obat tradisional yang dapat digunakan sebagai obat sekaligus tanaman hias di rumah masing-masing untuk mengurangi tingkat "karlota" atau menceritakan rumah tangga orang lain penyebab pertengkaran.

\section{Tujuan dan Manfaat Kegiatan}

Memberikan motivasi dan inovasi yang baru kepada masyarakat terutama kepada IbuIbu rumah tangga untuk mampu mengelola waktu dan kegugaran fisiknya yang dapat mendukung kesejahteraan rumah tangga dan sekaligus kesejahtraan dan keamanan lingkungan. Ditargetkan melalui kegiatan PKM ini akan meningkatkan semangat ibu-ibu PELWAP Desa Sea Mitra untuk memiliki pola hidup sehat dengan suka bersenam kebugaran dan menjadi gaya hidup sehingga rumah tangganya bahagia yang diawali dengan ibu rumah tangga yang bijaksana. Target lainnya diharapkan menjadikan cikal bakal tradisi di masyarakat PELWAP Desa Sea Mitra untuk berolah raga senam 1 kali setiap minggunya (minimal). Luarannya hasil uji Kebugaran yang menunjukkan adanya kemajuan Kebugaran dari sebelum diterapkannya PKM senam Jantung Sehat dan kebugaran ini ditambah pemanfaatan minuman fungsional pasote dan tapak dara akan meningkatkan kesehatan dan kebugaran PELWAP Desa Sea Mitra.

\section{METODE PELAKSANAAN}

\section{Sasaran Kegiatan Pengabdian}

Mitra pada kegiatan ini adalah seluruh anggota Pelayanan Wanita GPdI Sea Mitra dan pengurus UMK Biovina Herbal Sea Mitra.

\section{Lokasi Kegiatan Pengabdian}

Kegiatan dilaksanakan secara daring (online) di masa Pandemi Covid 19 ini melalui aplikasi Google meet untuk segala kegiatan sosialisasi dan penyuluhan serta koordinasi olah raga Kesehatan. Khusus praktek dan pelatihan menanam tumbuhan obat dan tanaman hias dan produk herbal dilakukan di Desa Sea Mitra Jaga II di Kebun Biovina Herbal sebagai percontohan (Gambar 1).

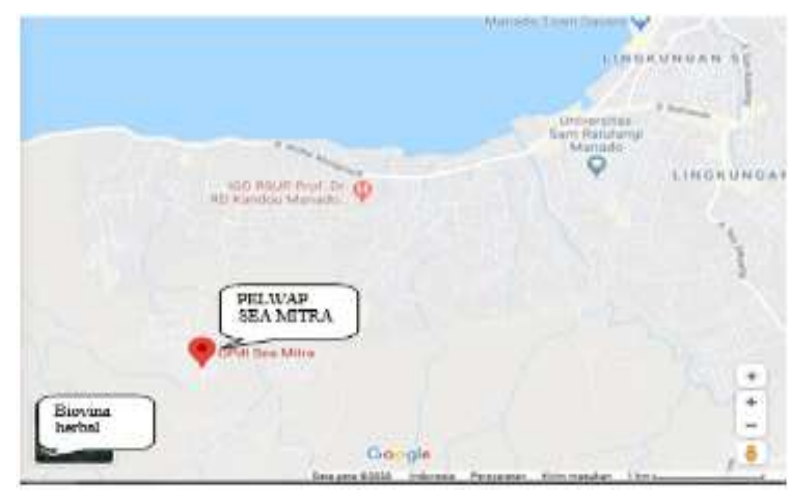

Gambar 1. Lokasi pelaksanaan kegiatan praktek dan pelatihan pembuatan percontohan kebun tumbuhan obat dan tanaman hias

\section{Metode Yang Digunakan}

Metode pelaksanaan kegiatan ini adalah:

1. Memberikan penyuluhan kepada mitra dengan topik bahasan antara lain:

- Pengenalan penyakit Covid 19 dan virus SARS Cov 2 yang yang bersifat bermutasi cepat.

- Pencegahan Pandemi Covid 19 dengan melakukan kelemahan kelemahan Covid 19

Seperti dikalahkan oleh antibodi dengan memanfaatkan tumbuhan obat, rusak karena sabun tahan panas dan dapat mati karena desinfektan. 
- Pentingnya jaga jarak, pakai masker, cuci tangan, makanan seimbang

- Tingkatkan imunitas dengan makanan sehat dan obat tradisional disekitar rumah

- Menjaga pikiran tetap tenang dan bersyukur dapat meningkatkan imunitas

- Olah raga dengan senam jantung sehat, manfaatnya dimasa Pandemi Covid 19. Tumbuhan obat tradisional yang sudah dibukukan "Etnobotani Tumbuhan obat Suku Sanger" sebagai rujukan yang terdapat sekitar 118 jenis tumbuhan obat disertai pemanfaatannya.

2. Memberikan percontohan dan pelatihan langsung kepada Mitra Biovina Herbal cara budidaya beberapa tumbuhan obat yang sekaligus jadi tanaman hias di masa pandemic Covid 19 antara lain tapak dara (Catharanthus roseus), pasote (Dysphania ambrosioides) dan markisa (Passiflora edulis) (Gambar 3) dan kecombarang (Eltingera eliator) (Gambar 4).

3. Sosialisasi dan Pelaksanaan Pemanfaatan Tumbuhan Obat Produk Penelitian Simplisia Biovina dan Teh Biovina

\section{- Penyuluhan atau Sosialisasi}

Pemateri atau pelaksanan memberikan pencerahan dan pengarahan tentang pengobatan tradisional dengan tumbuhan obat yang sekaligus dapat dijadikan tanaman hias. Materi yang diberikan secara sistematis sampai pada penemuan- penemuan hasil uji klinis obat-obatan herbal yang telah diproduksi oleh Biovana Herbal yang sudah dapat dimanfaatkan tanpa rasa ragu. Penyuluhan dan sosialisasi ini dilakukan pada hari Kamis tanggal 23 April 2020 secara daring melalui aplikasi Google meeting jam 19.0021.00.

\section{- Penerapan Pemanfaatan Tumbuhan obat dan Hias}

Produk Biovana Herbal dalam bentuk teh dan kapsul dari bahan dasar Pasote dan Tapak dara diperkenalkan dan disampaikan segala penelitian yang telah dilakukan. Kemudian bagi yang perlu pengobatan tekanan darah dan kolesterol akan diberikan komposisi dan jenis simplisia yang sesuai. Semua di tanyakan kesiapan dan kesediaannya. Bagi yang bersedia jadi peserta maka dilakukan pengecekan kesehatan lebih mendalam pada awalnya. Kemudian dikombinasi dengan oleh raga Senam setiap hari pagi-pagi kemudian minum the seduhan simplisia pasote tau tapak dara tergantung keinginan dan kebugaran yang akan di capai.

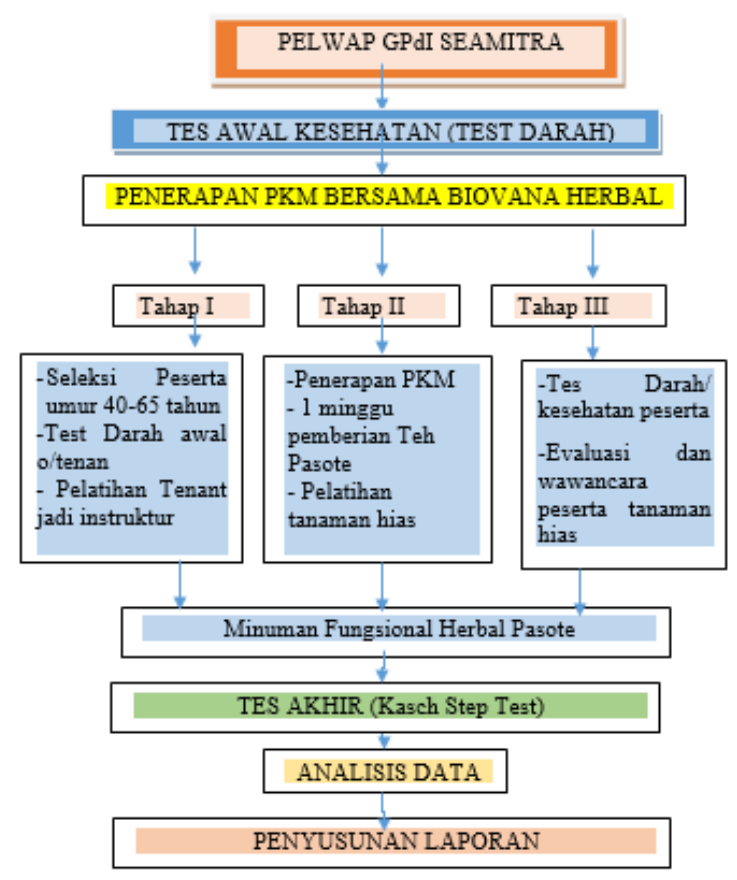

Gambar 2. Bagan pelaksanaan kegiatan PKM Tumbuhan Obat dan Hias di PELWAP GPdI Sea Mitra

4. Monitoring dan Evaluasi Kegiatan

Hasil penerapan terus dipantau sampai dua bulan berjalan dan dilakukan Tanya jawab mengenai kebugaran yang dirasakan para ibuibu. Disamping itu dilakukan pengukuran berat 
badan dan tinggi badan serta tekanan darah serta kandungan kolesterol atau gula darah. Hasil pengukuran dilakukan perbandingan dengan hasil pemeriksaan kebugaran sebelumnya antara lain: berat badan, tinggi badan, kebugaran, kolesterol, gula dan tekanan darah. Hasil yang diharapkan adalah meningkatkan kebugaran para ibu-ibu PELWAP GPdI Sea Mitra.

\section{HASIL KEGIATAN DAN PENERAPAN}

Tempat Kegiatan dapat dilihat di pada Gambar 1. Dan kegiatan awal yang dilakukan pada tanggal 23 April 2020 adalah sosialisasi program kemitraan melalui Google meet (Virtual) antara Penyuluh dari LPPM Unsrat dan dan Mitra sekaligus penerapan teknologi melalui penyampaian teknologi di makalah di Google Meet kepada para ibu-ibu jemaat PELWAP Desa Sea Mitra yang terlebih dahulu di bagikan dana tunai untuk penggantian kuota sebesar Rp. 200.000 dan dibarengi pemberian sembako yang diantar ke rumah masing masing oleh tim penyuluh (Gambar 3).

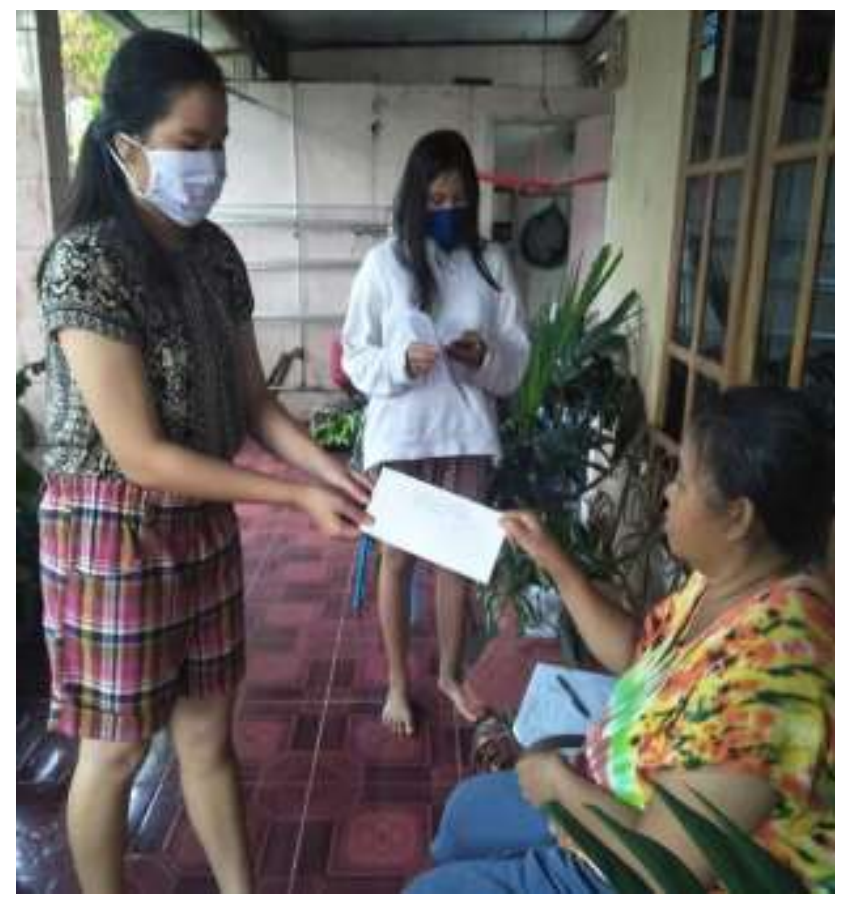

Gambar 3. Pembagian Dana Pengganti Kuota untuk Virtual Google Meet sebelum
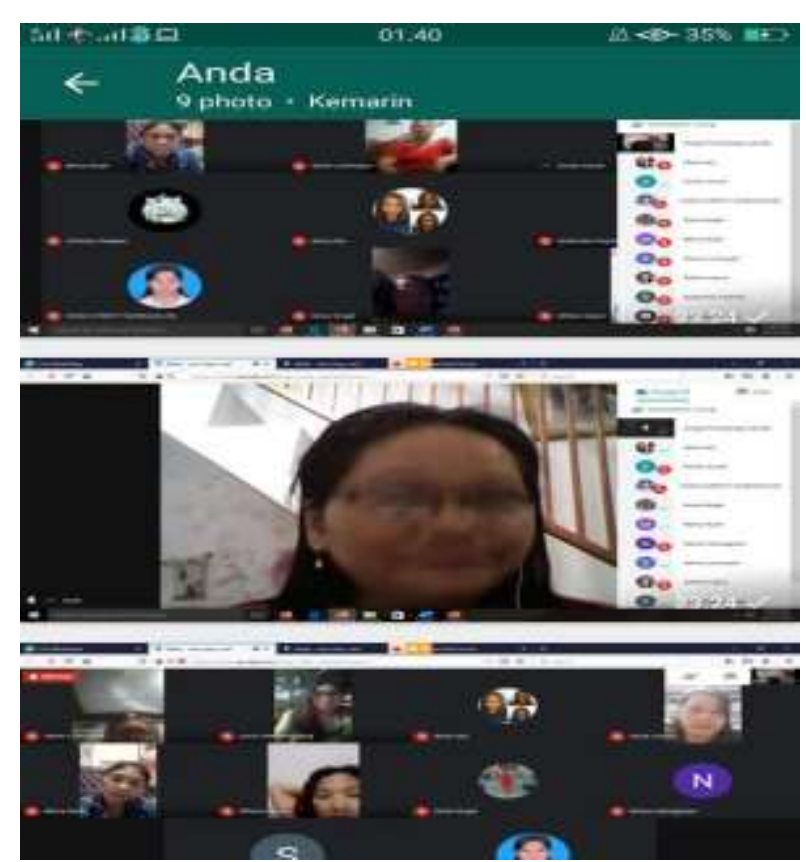

Sosialisasi dilakukan. Dana diantar ke rumah masing-masing.

Gambar 4. Para peserta dalam Vidio Conference Kegiatan Sosialisasi secara Virtual melalui kegiatan Google meet PKM Pelwab Desa Sea Mitra

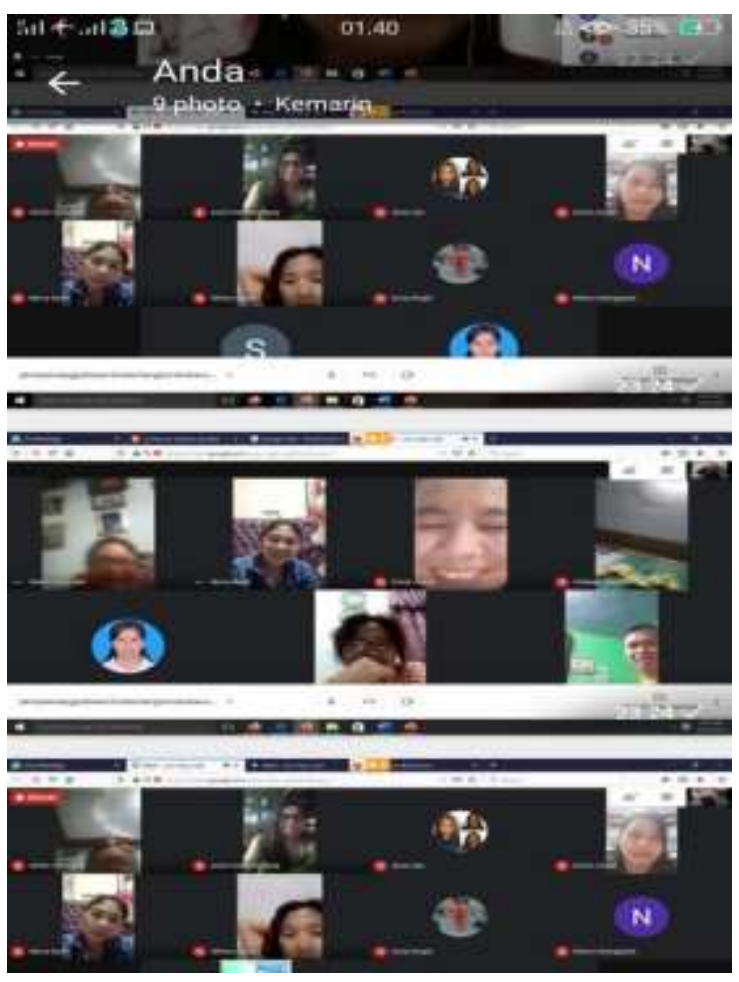

Gambar 5. Para peserta lainnya dalam Vidio Conference Kegiatan Sosialisasi secara Virtual melalui kegiatan Google Meet 
PKM Pelwab Desa Sea Mitra di pertengahan kegiatan

Tim pengusul yang berasal dari berbagai jurusan dan Fakultas di UNSRAT terdiri dari seorang ketua dan satu orang anggota yang semuanya merupakan dosen UNSRAT tersebut. Masing-masing anggota tim pengusul mempunyai keahlian yang saling sinergi dan berelevansi serta mempunyai pengalaman kemasyarakatan. Prof. Dingse Pandiangan, M.Si sebagai ketua tim mempunyai keahlian dibidang di bidang PKM ini terkait dengan Kesehatan dan Kebugaran Ibu-Ibu PKK (Pandiangan dan Nainggolan, 2016). Latar belakang penelitian Tumbuhan obat dan Kesehatan di Jurusan Biologi lebih khusus tentang Kebugaran dan kegiatan sosial masyarakat. Anggota pelaksana Paulina Y. Lamlean, S.Si, M.Kes Apt sebagai anggota mempunyai keahlian Ilmu Farmasi, kesehatan dan obat obatan serta pengalaman sebagai pendamping Program Kreativitas Mahasiswa dan pengabdian masyarakat. Jadwal kegiatan dari program ini dimulai dengan pengurusan ijin dan administrasi, pelaksanaan penerapan program ke kelompok sasaran yaitu kelompok usaha Biovina Herbal, dan kelompok PELWAP

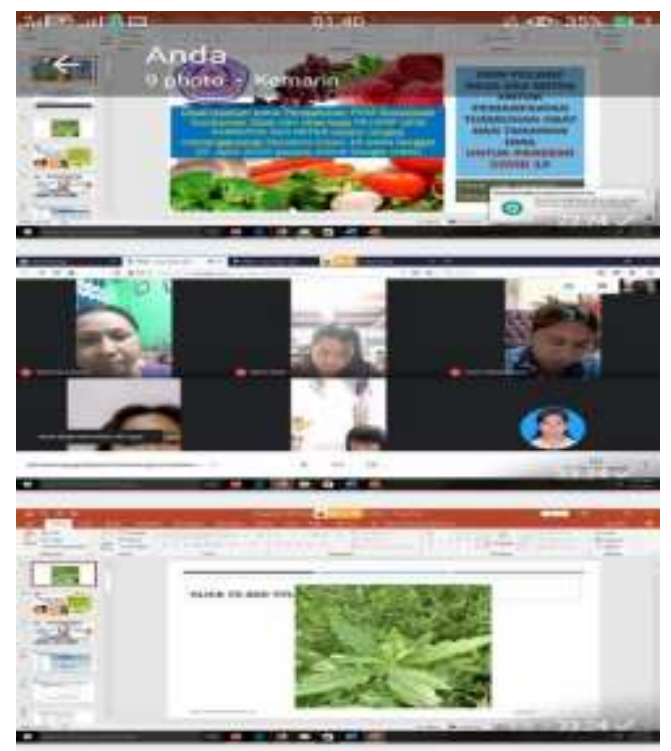

GPdI Desa Sea Mitra (Gambar 4 dan 5)

Gambar 6. Materi dan gambaran proses kegiatan Sosialisasi secara Virtual melalui kegiatan Google meet (video Conference)
PKM PELWAP Sea Mitra tentang Tumbuhan Obat dan Tanaman Hias

Salah satu kegiatan sosialisasi dan penyuluhan dimasa Pandemi ini dilakukan melalui kegiatan Vidio Conference dengan google meet seperti yang ditayangkan pada youtube https://youtu.be/o6Sq_sex9z0 (Gambar 4,5 dan 6). Vidio tersebut diperoleh melalui kegiatan PKM ini dapat meningkatkan semangat ibu-ibu rumah tangga untuk memiliki pola hidup sehat dengan menggunakan tanaman sekitar sebagai tumbuhan obat sekaligus tanaman hias dan suka bersenam kebugaran yang menjadi gaya hidup sehingga rumah tangganya bahagia yang diawali dengan ibu rumah tangga yang bijaksana (Gambar 4,5 dan 6). Hasil lainnya menciptakan tradisi baru di Di Desa Sea Mitra untuk menggunakan tumbuhan obat dan hias disekitar rumah serta berolah raga senam 1 kali setiap minggunya (minimal) dirumah masing-masing dengan memberikan rekaman senam jantung sehat bagi ibu-ibu di rumah saja. Luarannya hasil uji kebugaran yang menunjukkan adanya kemajuan kebugaran dari sebelum diterapkannya PKM senam jantung sehat dan kebugaran ini.

Target di mitra Biovina Herbal adalah adanya panduan dan jenis tumbuhan obat baru untuk pengembangan usaha mereka sekalian promosi produk mereka.

Materi yang diberikan:

- Tim peneliti dari Taiwan dan Australia menemukan bahwa sebuah strain virus corona penyebab Covid-19 di India mengalami mutasi yang bisa mengancam pengembangan vaksin.

- Laporan yang dipublikasikan di situs biorxiv.org; mutasi terjadi pada bagian protein spike (tonjolan mahkota) virus corona.

- Mutasi terjadi pada struktur receptorbinding domain (RBD) yang mengait pada reseptor ACE2 di sel manusia agar virus bisa menginfeksi. Dengan membuang satu ikatan hidrogen pada protein spike, mutasi tersebut mengurangi kemungkinan virus 
mengikat pada reseptor ACE2 yang ditemukan pada jaringan paru-paru dan organ lainnya.

- Artinya, vaksin yang menarget protein spike ini mungkin tidak akan bekerja pada pasien yang mengalami terinfeksi virus corona dengan mutase varian dimaksud.

- Tidak bergerak dan mengikuti kemauan manusia (hewan bergerak)

- Hanya tumbuhan yang berperan sebagai produsen pada rantai makanan dalam kehidupan atau ekosistem.

- Kehidupan lainnya dekomposer (pengurai) dan Konsumen (Hewan)

- Untuk hidup manusia tumbuhan penghasil oksigen (02) untuk pernapasan menggerakkan metabolisme.

- CO2 yang dihasilkan manusia digunakan oleh tumbuhan untuk proses fotosintesis menghasilkan bahan bermanfaat sebagai pangan, obat, sayuran, rempah-rempah (senyawa organik) seperti glukosa /pati/karbohidrat yang digunakan manusia dalam makanan, kemudian
- Pada tumbuhan juga (seperti Pasote, Tapak dara, Gedi, Jeruk, Apel, stroberi dll) terkandung zat antioksidan yang dibutuhkan manusia untuk mengatasi Covid 19 dengan meningkatkan kekebalan tubuh sehingga dapat mengalahkan serangan dan bahkan membunuhnya

- Memandangi bahkan memanen tumbuhan disekitar rumah saja sangat membantu mengatasi stress dampak pandemic Covid 19, sekaligus menhirup udara segar kaya oksigen.

- Bahan tanaman obat (kumis kucing,tapak dara, pasote, gedi, mayana,.dll

- Menanam disekitar rumah menjadi sarana hiburan dan olahraga bagi keluarga yang mengasikkan dan membahagiakan.

- Tumbuhan dan manusia saling memberi dan membantu mengatasi masalah Pandemi Covid 19
MENIKMATI

BERSAMA

HASIL

MENANAN HIDROPONIK

https://www.slideserve.com/e rice/teknologi-hidroponikpada-tanaman-buah-buahan

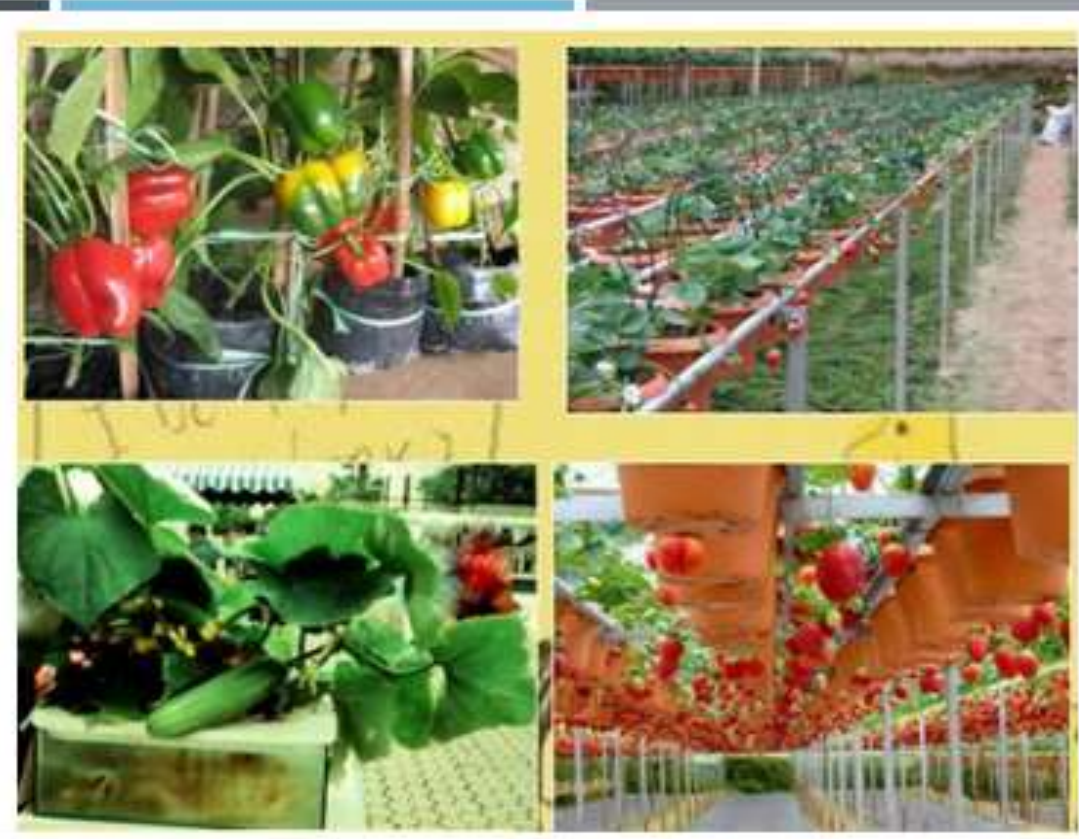

Gambar 7. Di perkotaan atau lahan sempit bisa dikembangkan tenik Hidroponik 
Hasil sosialisasi dimasa Pandemi Covid 19 ini dilakukan melalui kegiatan Vidio Conference dengan google meet seperti yang ditayangkan pada youtube https://youtu.be/o6Sq_sex9z0, diperoleh melalui kegiatan PKM ini dapat meningkatkan semangat ibu-ibu rumah tangga untuk memiliki pola hidup sehat dengan menggunakan tanaman sekitar sebagai tumbuhan obat sekaligus tanaman hias dan suka bersenam kebugaran yang menjadi gaya hidup sehingga rumah tangganya bahagia yang diawali dengan ibu rumah tangga yang bijaksana. Hasil lainnya menciptakan tradisi baru di Di Desa Sea Mitra untuk menggunakan tumbuhan obat dan hias disekitar rumah serta berolah raga senam 1 kali setiap minggunya (minimal) dirumah masing-masing dengan memberikan rekaman senam jantung sehat bagi ibu-ibu di rumah saja. Luarannya hasil uji kebugaran yang menunjukkan adanya kemajuan Kebugaran dari sebelum diterapkannya PKM senam jantung sehat dan kebugaran ini. Target di Biovina Herbal adalah adanya panduan dan jenis tumbuhan obat baru untuk pengembangan Usaha mereka sekalian promosi produk mereka.

Beberapa tanaman obat tanaman hias yang dibuat jadi percontohan di pinggir jalanan Jaga II Desa Sea Mitra kecamatan Pineleng di depan UMK Biovina Herbal (Gambar 8). Tumbuhan obat yang juga sebagai tanaman hias seperti tapak dara (Cataharanthus roseus yang ada bunga ungu dan bunga putih), Pasote (Dysphania ambrosioides), kecombrang (Eltingera elatior), juga ada Markisa (Passiflora edulis) dan Mayana (Coleus scultellarioides) seperti yang terlihat di Gambar 8.
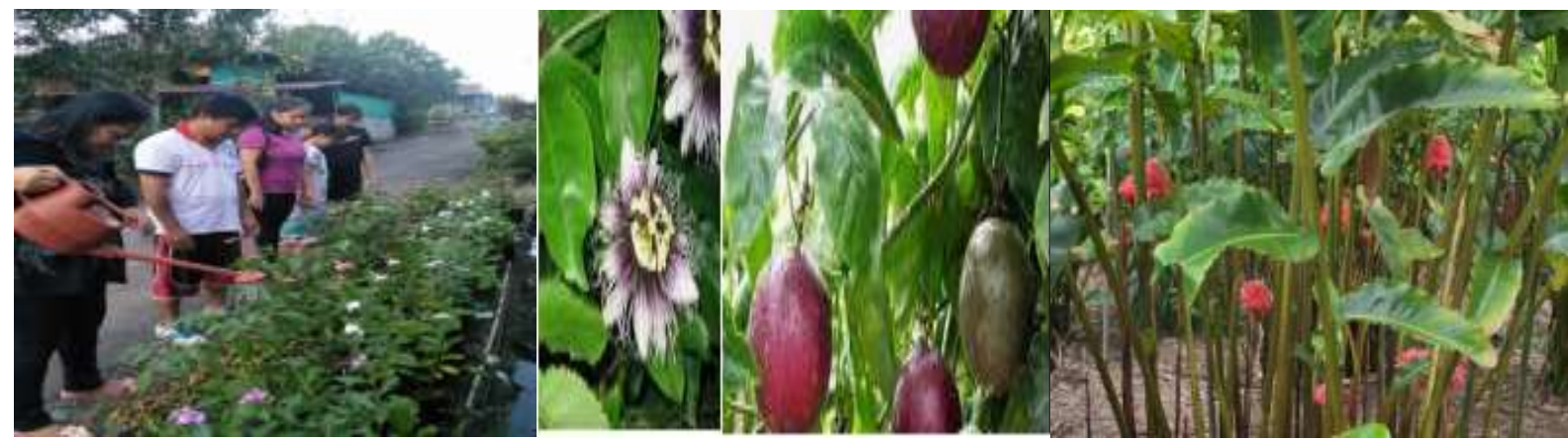

Gambar 8. Percontohan bersama keluarga menanam tanaman obat dan pangan sekaligus tanaman hias yang ditananam disekitar Biovina Herbal jadi percontohan bagi Desa Sea Mitra.

Pada Gambar tersebut sedang memberikan edukasi pentingnya tanaman tersebut di atas sebagai tanaman obat dan sudah dimanfaatkan masyarakat sekitar. Juga sudah dibuatkan dalam bentuk simplisia, teh (misalnya pasote) dan kapsul (Gambar 9). Pada Gambar tersebut sedang diberikan kepada salah satu Ibu-Ibu peserta PELWAP GPdI Khristos Sea Mitra yang dibagikan kerumah masing-masing bagi yang membutuhkan ramuan hasil bertanam di sekitar rumah. Pada gambar 9 nampak seotrang ibu memegang 1 botol kapsul suplemen Biovina yang sdh diteliti dan aman pemanfaatannya (Pandiangan et al., 2020). Desa Sea Mitra juga sampai laporan ini dibuat sekitar 20 September 2020 masih dalam Zona hijau dari Pandemi Covid-19 (Gambar 9c) yang merupakan penyampaian dari Kuntua (Kepala Desa) Atrhur Maindoka. 

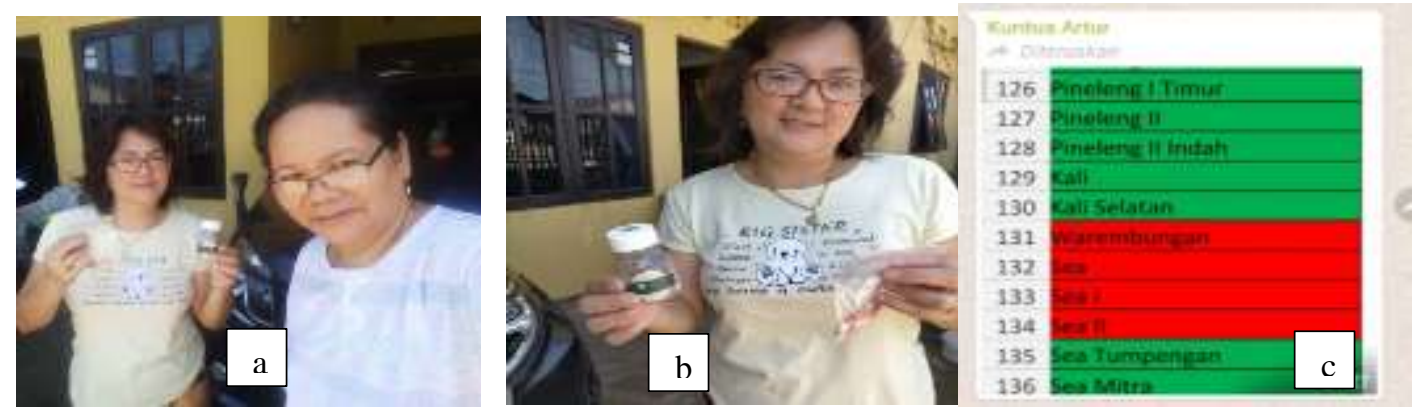

Gambar 9. Olahan tumbuhan obat dan pangan yang dijadikan suplemen yang di produksi di Biovina Herbal dan diberikan atau diantar ke rumah salah satu peserta Ibu Eva dan pelaksana (a) dan hasil Satgas Covid- 19 Desa Sea Mitra termasuk pada Zona hijau (c).

\section{KESIMPULAN}

Hasil kegiatan PKM ini dapat meningkatkan semangat ibu-ibu rumah tangga untuk memiliki pola hidup sehat dengan menggunakan tanaman sekitar sebagai tumbuhan obat sekaligus tanaman hias dan suka bersenam kebugaran yang menjadi gaya hidup sehingga rumah tangganya bahagia yang diawali dengan ibu rumah tangga yang bijaksana dan sehat. Hasil lainnya menciptakan tradisi baru di Desa Sea Mitra untuk menggunakan tumbuhan obat dan hias disekitar rumah serta berolah raga senam 1 kali setiap minggunya (minimal) dirumah masingmasing (dimasa Pandemi Covid 19) dengan memberikan rekaman senam jantung sehat bagi ibu-ibu di rumah saja. Luarannya hasil uji kebugaran yang menunjukkan adanya kemajuan kebugaran dari sebelum diterapkannya PKM senam jantung sehat dan kebugaran setelah kegiatan PKM ini. Peningkatan pemahaman tentang jenis jenis tumbuhan obat di mitra UMKM Biovina Herbal dan adanya panduan dan jenis tumbuhan obat baru untuk pengembangan Usaha mereka sekalian promosi produk Biovina. Kabar baik lainnya sampai laporan ini dibuat bahwa Desa Sea Mitra termasuk pada Zona Hijau dari dampak Pandemi Covid 19.

\section{UCAPAN TERIMAKASIH}

Ucapan terimakasih disampaikan kepada Rektor Universitas Sam Ratulangi dan Ketua LPPM UNSRAT atas penugasan pelaksanaan kegiatan ini dengan nomor surat 1153/UN12.13/PMPNBP/2020 pada tanggal 1 April 2020 atas bantuan dan dukungannya agar kegiatan ini dapat terlaksana dan memberikan dampak bagi masyarakat.

\section{DAFTAR PUSTAKA}

Anonim. 2007. Laporan Sport Development Index tahun 2006. Jakarta : Kementrian Negara Pemuda Dan Olahraga.

Erica.

2020

https://www.slideserve.com/erica/teknolo gi-hidroponik-pada-tanaman-buah-

buahan (akses 2 April 2020)

Giriwijoyo. 2003. Wanita dan Olahraga.

Jakarta. Fakultas Pendidikan

Olahraga dan Kebugaran,

Universitas Pendidikan Indonesia.

Mutohir, T. C, Maksum A. 2007. Sport Development Index. Konsep, Metodologi dan Aplikasi. Jakarta : PT Indeks. Nala, IGN. 1998. Prinsif Pelatihan Olahraga 
(Monograf). Denpasar: Program Studi Fisiologi Olahraga Program Pasca Sarjana Universitas Udayana.

Pandiangan D, Esyanti RR, de Queljoe E. 2008. Aktivitas Antikanker Katarantin pada sel mouse mammary cancer MmT06054. Jurnal lmiah Sains 8 (1) pp.107113.

Pandiangan D, Nainggolan N, Kandou F, de Queljoe E. 2018b. Effectiveness of Sambote Extract on Decreasing Blood Glucose Levels of Male White Rats (Rattus norvegicus) Induced with Sucrose. International Journal of Science and Research (IJSR) 7 (11): pp. 1683-1688.

Pandiangan D, Lamlean,P, Nainggolan N, Mailangkay H, 2020Antioxidant and Anticancer Activity Tests of "Pasote" Leaf Water Extracts (Dysphania ambrosioides L.) by In Vitro Method in Leukemia Cancer Cells. The $5^{\text {th }}$ International Conference on Basic Sciences IOP Conf. Series: Journal of Physics: Conf. Series 1463 IOP Publishing. DOI:10.1088/17426596/1463/1/012020

Pandiangan D, Nainggolan N, Mailangkay H, Tumbol M. 2018a. The Potential Use of Catharanthus roseus as a Beach Tourism Jewelry and as an Herbal Medicine for Tourists. The 3rd International Conference on Operations Research, Sam Ratulangi University, Manado, Indonesia, 20-21 September 2018 pp.74-84.

Pandiangan D, Nainggolan N, Mailangkay H, Tumbol M. 2020. Potential of
Anticholesterol Degeneratif

Drugs of Leaf Extract (Catharanthus roseus L.G. Don) on Wistar Rat (Rattus norvegicus). Sys Rev.Pharm. Volume 11 no 1: 618-625

Pandiangan D, Silalahi M, Dapas F, and Kandow F. 2019. Diversity of medicinal plants and their uses by the Sanger tribe of Sangihe Islands, North Sulawesi, Indonesia. Biodiversitas 20 (2): 621-631.

Pangemanan LD, Rondonuwu SJ. 1991. Bioekologi dan Inventarisasi Penggunaan Tumbuhan Tradisional di Kabupaten Bolang Mongondow. Universitas Sam Ratulangi, Manado.

Silalahi M, Nisyawati, Walujo EB, Supriatna J. 2015b. Local knowledge of medicinal plants in sub-ethnic Batak Simalungun of North Sumatra, Indonesia, Biodiversitas 16 (1): 44 
